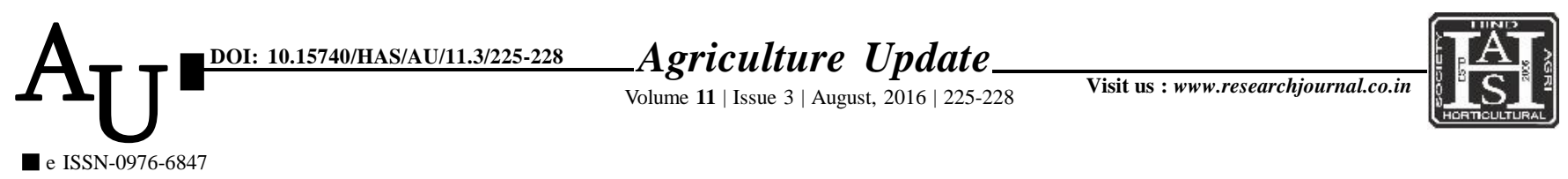

\title{
Rевевсн Автіск: Boosting of groundnut productivity through front line demonstration in the South Tripura district
}

\author{
MANDIRA CHAKRABORTI AND A.K.SINGH
}

Article Chronicle: Received :

23.05.2016;

Revised :

17.06.2016;

Accepted :

30.06.2016

KEY WoRDS :

Groundnut, Front line demonstration, South Tripura, Economics
SUMMARY : In South Tripura district groundnut is grown in very small pocket using local varieties. In general, farmers do not follow scientific package of practices and not using the improved variety due to which the productivity of groundnut is only $1200 \mathrm{~kg} / \mathrm{ha}$. With a view to increase the productivity level of groundnut in the district total 80 numbers of demonstration has been taken covering 17 ha area in six selected villages during Kharif and Rabi season of 2011 and 2012 by KVK, South Tripura. The objective of the FLD on groundnut was to demonstrate the potential of improved varieties and technologies to the farmers. Awareness programme and training on scientific cultivation practices of groundnut was conducted before starting the demonstration programme. Besides imparting training, printed leaflets on groundnut were distributed among the farmers for their ready reference. Field day programme was also conducted in the farmer's field in standing crop. Improved variety of groundnut viz., GG-7 and GG-20 were demonstrated for obtaining higher yield as compared to local varieties and traditional method of cultivation. Increase in yield percentage varies from 26.83 to 50.43 per cent for both the varieties over the local check. Farmers earned upto Rs. 38550/- for both the varieties by selling the groundnut in the local market.

How to cite this article : Chakraborti, Mandira and Singh, A.K. (2016). Boosting of groundnut productivity through front line demonstration in the South Tripura district. Agric. Update, 11(3): 225-228, DOI : 10.15740/ HAS/AU/11.3/225-228.
Author for correspondence :

\section{MANDIRA}

\section{CHAKRABORTI}

Krishi Vigyan Kendra, SOUTH TRIPURA (TRIPURA) INDIA

Email : cmandira1@ rediffmail.com

See end of the article for authors' affiliations 